Bioscientia Medicina: Journal of Biomedicine \&

Translational Research

Journal Homepage: www.bioscmed.com

\title{
Analysis of Family Planning Services in Mohammad Hoesin Hospital Palembang on 2016
}

\section{Firmansyah Basir ${ }^{1 *}$, Adik Wibowo ${ }^{2}$, Amal C Sjaaf $^{2}$}

1 Department of Obstetrics and Gynecology, Faculty of Medicine, Universitas Sriwijaya/ Dr. Mohammad Hoesin General Hospital, Palembang, Indonesia

2 Faculty of Public Health, Universitas Indonesia, Jakarta, Indonesia

\section{A R T I C L E I N F O}

\section{Keywords :}

Family planning

Hospital services

Public health

Community health

Descriptive study

*Corresponding author:

Firmansyah Basir

E-mail address:

firmansyahbasirspogagmail.com

All authors have reviewed and approved the final version of the manuscript.

https://doi.org/10.37275/bsm.v6i3.445

\begin{abstract}
A B S T R A C T
Background. Family planning services in hospitals have been held since 1970 by the functional implementing unit led by obstetric and gynecologist specialists. Situational changes following decentralization in the 1990 s caused policymakers and family planning practitioners' lack of attention to family planning services at province, district, and city levels. Data from 2002-2007 showed a decrease in family planning services from $6.2 \%$ to $4.9 \%$ in government hospitals and from $3.4 \%$ to $2.2 \%$ in private hospitals. The decrease in contraception use was affected by family planning users and providers. This study aims to analyze the factors contributing to family planning services in Mohammad Hoesin Hospital.

Methods. This was a descriptive-analytic study with a cross-sectional design. The author used primary and secondary data with quantitative and qualitative approaches through the study of documents, observation, questionnaire, in-depth interview, and focused group discussion.

Results. We identified various factors that play a role in the implementation of family planning services in almost all aspects, such as policy system, incomplete infrastructures; competence and the number of health workers; standard service procedure; sources and mechanism of the contraceptive tools; financial problems; recording and reporting system; quality control services; monitoring and evaluation; development services; also knowledge and behavior of the health workers.

Conclusion. Family planning services need support and more serious attention from the directors to improve and overcome the problems and obstacles. In addition, the board of directors requires better coordination effort and cooperation on the internal level (between divisions or departments within the hospital) and with the relevant instance.
\end{abstract}

\section{Introduction}

Family planning is an effort to increase the public's concern and roles through increasing the marriage age, controlling the birth rate, and building family resilience to create a small, happy, and prosperous family. ${ }^{1}$ The goal of family planning is to create a small family with its economy and social power through birth control to make a happy and well family that can fulfill their own needs ${ }^{2}$ Family planning services in a hospital are medical and non-medical services provided for fertile age couples by competent health service workers to delay, space, or end fertility period by one of the contraception methods available and managing complication and failure, including the possibility of recanalization.

Family planning services in the hospital has been held by a functional implementing unit led by obstetric and gynecologist specialist. Increasing the role of government and private hospitals in family planning services is one of the revitalization strategies of national family planning program in the hope to decrease mother and infant death according to millennium development goals number 4 and 5.3 Situational 
changes following decentralization in the 1990s cause the lack of attention to family planning services by policymaker and family planning practitioner at province, district, and city levels. Between 2002-2007 there was a decrease in family planning services from $6.2 \%$ to $4.7 \%$ in government hospitals and from $3.4 \%$ to $2.2 \%$ in private hospitals. This decrease was caused by family planning user and service provider factors. The absence of government obligation toward the hospital to provide family planning services has caused low coverage. Meanwhile, in most prominent hospitals, family planning program is not their priority. ${ }^{4}$

Therefore, this study aims to evaluate family planning services implementation, factors that cause and hinder implementation, and solutions to increase family planning services in Mohammad Hoesin Hospital. This study was aimed to describe hospital leaders' opinion and role in realizing effective, efficient, and satisfactory family planning services that meet international standards and directly improve woman, child, family, and social quality of life.

\section{Methods}

This was a descriptive-analytic study with a crosssectional design. The author used primary and secondary data with quantitative and qualitative approaches through the study of documents, observation, questionnaire, in-depth interview, and focused group discussion. The study was held in Mohammad Hoesin Hospital from October-December 2016. Input, process, and output factors were evaluated. Input factors consist of policymaking and organization, human resources, and infrastructure of family planning services. Process factors consist of services and registration and monitoring of family planning. Output factor is the result of family planning services. The sample population was all health care workers that provide family planning services in Mohammad Hoesin hospital (specialist, doctor, and midwife). Data were collected through a questionnaire that has been validated. Data analysis was performed with a statistical approach with univariate and bivariate analysis.

Qualitative data was collected through interview to 5 informants from hospital managerial, Badan
Kependudukan dan Keluarga Berencana Nasional (BKKBN) representatives from South Sumatera and Palembang, Palembang public health office, and family planning services managerial in Mohammad Hoesin hospital. Focus group discussion was held for three groups, midwife, doctor, and specialist. Data validation was performed through the method and source validation. Content analysis was used to analyze data, so it is easier to make the transcript, result, and discussion of a qualitative study. The sample size for midwife and doctor behavioral observation in family planning counseling was calculated with the Lemeshow formula, resulting in a minimal sample size of 20 midwives and 30 doctors.

\section{Results}

\section{Policymaking and organization of family planning services}

There is no distinct structural organization that implements the family planning services in Mohammad Hoesin Hospital. There is also no decree from the hospital director to make family planning services as its own unit. The services provided in this hospital is still based on BKKBN program and integrated by all hospital units involved in family planning services, especially counseling and internal reference, to increase potential family planning user. As a vertical hospital, the implementation of family planning services is coordinated with different institutions, including the main BKKBN, South Sumatera BKKBN, Palembang BKKBN, local government, public health office, and organization. A memorandum of understanding (MOU) is needed when hospitals collaborate with institutions in implementing family planning services.

The authors found that Palembang BKKBN did not have an MOU with Mohammad Hoesin Hospital at a central policy level. At the service level, the authors found that family planning services are not held by the distinct structural organization in the hospital. Some interviewees thought that family planning programs are mostly performed at primary health facilities; therefore, hospitals only refer to complex cases. 


\section{Human resources in family planning services}

We found no significant relation between age and educational level, educational level and length of working, and education status with education level in midwife, doctor, and specialist (table 1).

Table 1 . The characteristic of human resources involved in family planning services

\begin{tabular}{|c|c|c|c|c|c|c|c|}
\hline \multirow{2}{*}{\multicolumn{2}{|c|}{ Variable }} & \multicolumn{2}{|c|}{ Midwife } & \multicolumn{2}{|c|}{ Doctor } & \multicolumn{2}{|c|}{ Specialist } \\
\hline & & $\mathrm{N}$ & $\%$ & $\mathrm{~N}$ & $\%$ & $\mathrm{~N}$ & $\%$ \\
\hline $\begin{array}{r}\text { Age } \\
- \\
-\end{array}$ & $\begin{array}{l}\geq 30 \text { years } \\
<30 \text { years }\end{array}$ & $\begin{array}{l}27 \\
24\end{array}$ & $\begin{array}{l}52,9 \\
47,1\end{array}$ & $\begin{array}{l}36 \\
27\end{array}$ & $\begin{array}{l}57,1 \\
42,9\end{array}$ & $\begin{array}{c}18 \\
0\end{array}$ & $\begin{array}{c}100 \\
0\end{array}$ \\
\hline $\begin{array}{r}\text { Gend } \\
- \\
-\end{array}$ & $\begin{array}{l}\text { Male } \\
\text { Female }\end{array}$ & $\begin{array}{c}0 \\
51 \\
\end{array}$ & $\begin{array}{c}0 \\
100 \\
\end{array}$ & $\begin{array}{l}42 \\
20 \\
\end{array}$ & $\begin{array}{l}67,74 \\
32,26 \\
\end{array}$ & $\begin{array}{c}13 \\
5 \\
\end{array}$ & $\begin{array}{l}72,22 \\
27,78 \\
\end{array}$ \\
\hline $\begin{array}{r}\text { Lengt } \\
- \\
-\end{array}$ & $\begin{array}{l}\text { f working } \\
\leq 10 \text { years } \\
>10 \text { years }\end{array}$ & $\begin{array}{l}41 \\
10 \\
\end{array}$ & $\begin{array}{l}80,4 \\
19,6 \\
\end{array}$ & & & $\begin{array}{c}10 \\
8 \\
\end{array}$ & $\begin{array}{l}55,6 \\
44,4 \\
\end{array}$ \\
\hline $\begin{array}{r}\text { Comp } \\
- \\
- \\
-\end{array}$ & $\begin{array}{l}\text { nce level } \\
0-<2 \text { years } \\
2-3 \text { years } \\
>3 \text { years }\end{array}$ & & & $\begin{array}{c}9 \\
40 \\
14\end{array}$ & $\begin{array}{l}14,3 \\
63,5 \\
22,2\end{array}$ & & \\
\hline $\begin{array}{r}\text { Educe } \\
- \\
- \\
- \\
\end{array}$ & $\begin{array}{l}\text { < undergraduate } \\
\text { Undergraduate } \\
\geq \text { postgraduate }\end{array}$ & $\begin{array}{c}46 \\
1 \\
3 \\
\end{array}$ & $\begin{array}{c}92,2 \\
2,0 \\
5,9 \\
\end{array}$ & $\begin{array}{c}0 \\
63 \\
0 \\
\end{array}$ & $\begin{array}{c}0 \\
100 \\
0 \\
\end{array}$ & $\begin{array}{c}0 \\
0 \\
18 \\
\end{array}$ & $\begin{array}{c}0 \\
0 \\
100 \\
\end{array}$ \\
\hline $\begin{array}{r}\text { Beha } \\
- \\
- \\
-\end{array}$ & $\begin{array}{l}\text { Ar } \\
\text { Supportive } \\
\text { Less supportive } \\
\text { Not support }\end{array}$ & $\begin{array}{c}51 \\
0 \\
0 \\
\end{array}$ & $\begin{array}{c}100 \\
0 \\
0 \\
\end{array}$ & $\begin{array}{c}63 \\
0 \\
0 \\
\end{array}$ & $\begin{array}{c}100 \\
0 \\
0 \\
\end{array}$ & $\begin{array}{c}18 \\
0 \\
0 \\
\end{array}$ & $\begin{array}{c}100 \\
0 \\
0 \\
\end{array}$ \\
\hline Total & & 51 & 100 & 63 & 100 & 18 & 100 \\
\hline
\end{tabular}

Table 2 describes the result of behavioral observation on midwife and doctor when giving family planning counseling. From midwife and doctor behavioral observation in giving counseling, we found that only 9 (28.1\%) midwives and 17 (53.1\%) doctors use visual aid when giving counseling. Besides that, all midwives and doctors treat patients with a friendly attitude and guarantee confidentiality.

Table 2. Behavioural observation results

\begin{tabular}{|c|c|c|c|}
\hline \multirow[t]{2}{*}{ No } & \multirow[t]{2}{*}{ Category } & \multicolumn{2}{|c|}{ Description } \\
\hline & & Midwife $(\mathrm{n}=32)$ & Doctor $(\mathrm{n}=32)$ \\
\hline 1 & Worker greets patient with friendly attitude & $32(100)$ & $32(100)$ \\
\hline 2 & Worker introduces him/herself & $32(100)$ & $31(96,9)$ \\
\hline 3 & Worker asks for patient's purpose & $27(84,4)$ & $30(93,8)$ \\
\hline 4 & Worker treats patient respectfully & $26(81,2)$ & $23(71,9)$ \\
\hline 5 & Worker guarantees patient confidentiality & $32(100)$ & $32(100)$ \\
\hline 6 & Worker gives general information regarding family planning & $26(81,2)$ & $29(90,6)$ \\
\hline 7 & $\begin{array}{l}\text { Worker gives information regarding different contraceptive methods } \\
\text { avaialble }\end{array}$ & $17(53,1)$ & $28(87,5)$ \\
\hline 8 & $\begin{array}{l}\text { Worker provides information regarding the risk and benefit of each } \\
\text { contraceptive methods and the different between permanent and } \\
\text { reversible contraception }\end{array}$ & $13(40,6)$ & $29(90,6)$ \\
\hline 9 & $\begin{array}{l}\text { Explain the choice of contraceptive methods suitable for the } \\
\text { patients }\end{array}$ & $19(59,4)$ & $29(90,6)$ \\
\hline 10 & Explain how contraception works & $16(50,0)$ & $27(84,4)$ \\
\hline 11 & Explain the contraindication and requirement for contraceptive use & $17(53,1)$ & $29(90,6)$ \\
\hline 12 & $\begin{array}{l}\text { Explain the side effect, complication, and rate of failure of } \\
\text { contraceptive methods }\end{array}$ & $18(56,2)$ & $29(90,6)$ \\
\hline 13 & Explain the benefit and loss of contraceptive use & $18(56,2)$ & $31(96,9)$ \\
\hline 14 & Explain the process or procedure of contraception methods & $17(53,1)$ & $23(71,9)$ \\
\hline 15 & Counsellor asks the patient with open question & $24(75)$ & $27(84,4)$ \\
\hline 16 & Counsellor encourages patient to ask question & $23(71,9)$ & $27(84,4)$ \\
\hline 17 & Worker treats client respectfully & $32(100)$ & $32(100)$ \\
\hline 18 & Worker convinces patient personally & $26(81,2)$ & $28(87,5)$ \\
\hline 19 & $\begin{array}{l}\text { Worker discusses patient's need, consideration, and concern with } \\
\text { sympathetic attitude }\end{array}$ & $26(81,2)$ & $25(78,1)$ \\
\hline 20 & Worker uses visual aids & $9(28,1)$ & $17(53,1)$ \\
\hline 21 & Worker helps client choosing the right contraceptive methods & $22(68,8)$ & $30(93,8)$ \\
\hline 22 & Worker use patient's medical record & $21(65,6)$ & $27(84,4)$ \\
\hline
\end{tabular}


Infrastructures in family planning services

The infrastructure for family planning services is integrated into obstetric and gynecologist units, surgery units, and other units. The infrastructure for family planning in Mohammad Hoesin Hospital consists of short- and long-term contraception, managing side effects, complications, and failure, and managing reproductive health problems. However, this hospital lacked room for handwashing, no-scalpel vasectomy, a mini laparoscopic kit, and equipment for tube recanalization. Contraception was supplied by central BKKBN then distributed to South Sumatera BKKBN to Palembang BKKBN and Mohammad Hoesin Hospital according to request and report.

\section{Financing of family planning services}

The source of financing for family planning services in Mohammad Hoesin Hospital comes from Anggaran Pendapatan dan Belanja Negara (APBN), BKKBN, Anggaran Pendapatan dan Belanja Daerah (APBD), Badan Penyelenggara Jaminan Sosial (BPJS), and others. The cost of family planning services in Mohammad Hoesin Hospital consists of doctor consultation, service cost, hospital cost, and tools and disposables. The cost for family planning services in the hospital is only covered by BPJS for Women's Operative Method Contraception (MOW), while insertion and removal of IUD and implant were performed in a primary health care facility. The cost of MOW service following delivery or cesarean section is already included in BPJS package. The cost for interval MOW has not been determined yet.

BKKBN South Sumatera has prepared the fund for IUD, implant, and MOW training. This fund can be claimed from province BKKBN through Palembang BKBPP according to family planning services performed every month. This fund is reserved for counseling costs and not operating costs. The fund for IUD insertion is 125,000 rupiah, for implant insertion is 90,000 rupiah, for implant removal is 100,000 rupiah, and for MOW is 550,000 rupiah.

\section{Family planning services}

The family planning services are performed by first identifying the client. We then performed an interview, completed the patient's medical record, and counseled the patient in choosing the right contraception. In exceptional cases such as patients with side effects or complications, we must first address this issue before counseling the patient. Post-delivery contraception is the main priority for family planning services in Mohammad Hoesin Hospital. The patients were recommended to get the procedure done before discharge. Family planning service is according to the operational procedure standard. Mohammad Hoesin Hospital received a referral for family planning services from another hospital. Cases referred to our hospital include failure or severe complications and the need for more advanced technology.

\section{Recording, reporting, monitoring, and evaluation of family planning services}

Mohammad Hoesin General Hospital recorded the implementation of family planning services and periodically reported it. We use the form from BKKBN to record and report the implementation of family planning services. Report was sent to Kemuning district of Palembang city, then forwarded to Palembang BKKBN/BKBPP, then to South Sumatera $\mathrm{BKKBN}$, and finally to main BKKBN. Recording and reporting of family planning services do not follow the hospital information system. We report the data every year.

Evaluation and monitoring of family planning services are not performed by Mohammad Hoesin Hospital but by province BKKBN. They evaluate contraception availability every month and doctor competence every year. Internal evaluation by the hospital has not been performed before. BKKBN directly monitors and evaluates the family planning service in Mohammad Hoesin Hospital as it is directly related to contract procurement. 


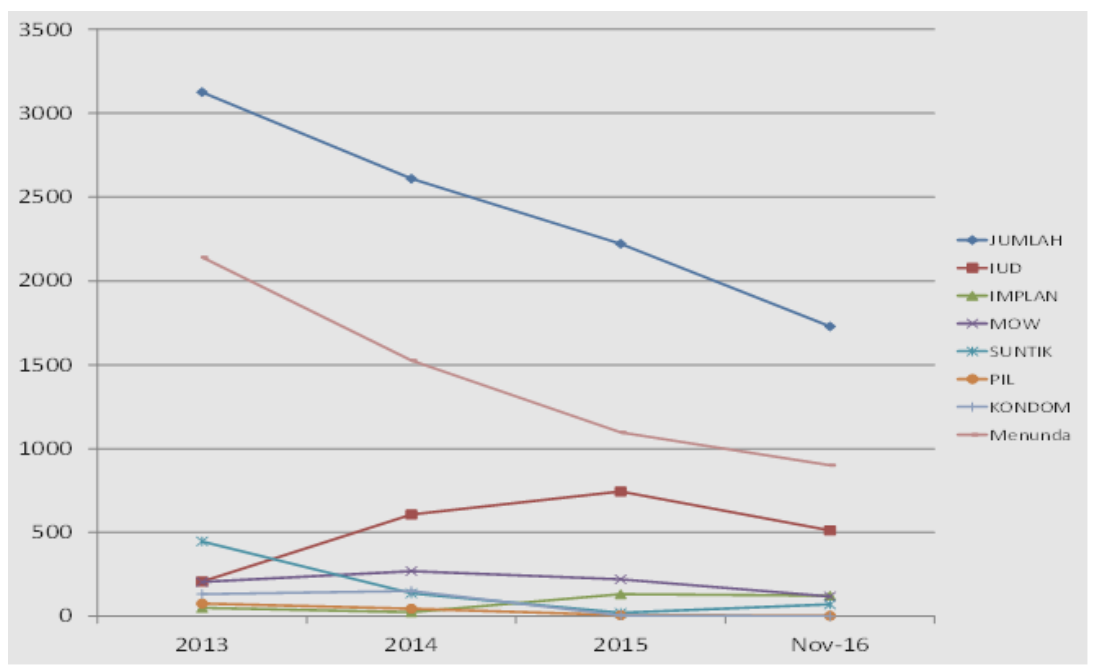

Figure 1. Family planning service trend

Evaluation of family planning services results in the past four years showed a decreasing trend from 3,126 services in 2013 to 1,729 services in November 2016. Oral contraception, injection contraception, and condom decreased while MOW remained relatively stable. On the contrary, IUD and implant contraception showed increment. Figure 1 shows the family planning services trend in Mohammad Hoesin Hospital between 2013 to 2016. From figure 1, we can see a decreasing trend of family planning services in Mohammad Hoesin Hospital for the last four years (2013 to November 2016). However, we observed an increase in the number of patients that received contraception before hospital discharge.

\section{Discussion}

\section{Policy making and organization of family planning service}

The World Health Organization (WHO) stated that government and the public sector are the primary keys constitutionally responsible for making policy and regulation and providing comprehensive health care service. 5 The Department of Health and Wellbeing, the Directorate General of Health and Family Planning Services, manages health care and family planning services. The local government manages primary health care services in the city. The quality of service is considered low due to limited resources, institutional limitations, and the absence or failure of health care providers.
Currently, the family planning services in Mohammad Hoesin Hospital proceed without a clear structural organization. This leads to the implementation of services without a clear plan or goal. The government has made various attempts to increase family planning services in the hospital. The Department of Health issued an appeal letter in February 2009 to the hospital director to increase family planning services in the hospital by forming a Hospital Family Planning Services Team under the hospital director consisting of various disciplines and involving another hospital unit. Forming this team aims to increase and develop high-quality family planning services while ensuring patient safety. The absence of quality control through routine monitoring and evaluation systems caused no further improvement in the achievement and quality of family planning service. Hospital managerial support and commitment are needed to improve family planning service in Mohammad Hoesin Hospital.

\section{Human resources in family planning service}

Our study showed that $88 \%$ of midwives have low education status. This could be caused by various factors, such as the lack or absence of training on family planning, the lack of supervision, monitoring, and evaluation by Mohammad Hoesin Hospital, and services delivery without improvement or development. Government policy on Pelatihan Teknologi Kontrasepsi Terkini (TKT) was one of various efforts to prepare a 
competent family planning practitioner. From behavioral observation when giving counseling, we found that only 9 (28.1\%) midwives and 17 (53.1\%) doctors used visual aid. Information regarding the risk and benefit of each contraceptive method and the mechanism of contraception action is only explained by 13 (40.6\%) and 16 (50\%) midwives, respectively. All midwives and doctors treat the patient with a friendly attitude.

These problems might be due to the lack of several midwives compared to the patient, lack of visual aid for family planning counseling, and the low knowledge level of midwives regarding family planning in Mohammad Hoesin Hospital. Prata et al., 6 reported a significant relation between midwives' knowledge and family planning (IUD) service behavior; the better their knowledge, the better their behaviors. Afulani et al., reported that low IUD usage was due to acceptor regarding IUD benefits. The lack of workers' knowledge could cause this problem. ${ }^{7}$

\section{Infrastructures in family planning services}

Infrastructures for family planning services in Mohammad Hoesin Hospital are incorporated in other units. This raises problems as it disturbs family planning services. Approximately 1 million women with unmet family planning needs can be reduced if the hospital provides family planning services. The Department of Health assigned all government hospitals to provide family planning services as basic services. However, there is much variation regarding the services provided even in government hospitals. This issue highlights the need for a guideline for a hospital in delivering family planning services. Hospital family planning services consist of delivering information to the client, counseling, preparing pills, injection, and condom; insertion and removal of IUD and implant, bilateral tube ligation through minilaparotomy with a local anesthetic, and no-scalpel vasectomy; supporting the practice of natural family planning method such as cervical mucous, basal body temperature, symptothermal, and amenorrhea lactational method; and management of complications and side effects following contraceptive use. Family planning services must be available in different hospital sections or units. Every unit is expected to decrease the unmet need for family planning by providing a key message for family planning, client counseling, and at least giving pills, injections, and condoms. ${ }^{7}$

\section{Financing of family planning services}

The family planning services in Mohammad Hoesin Hospital came from APBN, BKKBN, APBD, BPJS, and other sources. South Sumatera BKKBN also prepared funds for IUD, implant, and MOW counseling. This fund can be claimed to province BKKBN through Palembang BKBPP according to family planning services performed every month. It should be noted that this fund is used for counseling and education, not for the procedural cost.

\section{Family planning services}

Family planning services in Mohammaed Hoesin Hospital is classified as complete and supported by: obstetric and gynecologist and fertility consultant, urologist, anesthesiologist, and midwives. Mohammad Hoesin Hospital has yet to have an andrologist. As a vertical hospital, Mohammad Hoesin Hospital provided family planning services for referral cases of family planning complication and failure and management with more advanced technology. Family planning is considered as a program for primary health care facilities, while Mohammad Hoesin Hospital, as tertiary health care facilities, mostly managed referral patients. Mohammad Hoesin Hospital does not perform evaluation/self-assessment or monitoring from the quality maintenance team. In order to increase the quality of family planning service, Mohammad Hoesin Hospital must perform evaluation/self-assessment, monitoring from the quality maintenance team, and accreditation every five years to measure the quality of service provided.

\section{Recording, reporting, monitoring, and evaluation of family planning services}

Mohammad Hoesin Hospital records and reports family planning service using BKKBN form, except for family planning clinic registration card, which uses patient's medical record. The recording and reporting of 
family planning services do not follow the Hospital Information System and are performed annually. Data and information of family planning services can be used as material for decision making, planning, monitoring, evaluation, and controlling of family planning services from the National Health Coverage program. Therefore, data and information provided must be accurate, on time, and trusted. Recording and reporting of family planning services in National Health Coverage are performed based on a procedural, operational standard of the National Family Planning Program. Its practice is based on information technology that was recently updated in 2014. The activity of family planning recording and reporting consists of family planning services, the result of family planning services, and stock of contraception in family planning facilities.

Monitoring and evaluation of family planning services aim to see the development of service and the correlation between program planning and execution. 8 Meanwhile, evaluation of family planning service aims to see the level of achievement of success indicator. The family planning workgroup performs monitoring and evaluation periodically in National Health Coverage through coordination meetings and field supervision. Mohammad Hoesin Hospital does not monitor and evaluate family planning services. The province BKKBN ensures contraception stock availability every month and to evaluates doctor competence every year.

\section{Conclusion}

We identified various factors that play a role in the implementation of family planning services in almost all aspects, such as policy system, incomplete infrastructures; competence and number of health workers; standard service procedure; sources and mechanism of the contraceptive tools; financial problems; recording and reporting system; quality control services; monitoring and evaluation; development services; and knowledge and behavior of the health workers. Family planning services need support and more serious attention from the directors to improve and overcome the problems and obstacles.
In addition, the board of directors requires better coordination effort and cooperation on the internal level (between divisions or departments within the hospital) and with relevant instance.

\section{References}

1. Huda N, Baroya N, Sandra C, Hariastuti I. Family planning village program in response to the use of long-term contraceptive methods. J Admin Kesehatan Indo. 2020; 8(1)

2. Titaley CR, Sallatahohy N. Utilization of family planning contraceptives among women in the coastal area of south Buru district, Maluku, 2017. Kesmas. 2020; 15(1).

3. BKKBN. Guidelines for family planning services in hospitals. Jakarta: Ministry of Health; 2010.

4. Winarni E, Dawam M. Family planning information, education and communication with contraceptive use. Kesmas. 2016; 11(2).

5. Agus Y, Pamungkasari EP, Soemanto RB. Theory of planned behavior: determinants of the use of modern family planning method. J Maternal Child Health. 2019; 4(5).

6. Prata N, Fraser A, Huchko MJ, Gipson JD, Withers M, et al. Women's empowerment and family planning: a review of the literature. $\mathrm{J}$ Biosoc Sci. 2017; 49(6): 713-43.

7. Afulani PA, Altman M, Musana J, Sudhinaraset M. Conceptualizing pathways linking women's empowerment and prematurity in developing countries. BMC Pregnancy Childbirth. 2017; 17(Suppl 2): 338.

8. Yaya S, Uthman OA, Ekholuenetale M, Bishwajit G. Women empowerment as an enabling factors of contraceptive use in subSaharan Afrca: a multilevel analysis of crosssectional surveys of 32 countries. Reprod Health. 2018; 15(1): 214. 